\title{
Bank erosion and large wood recruitment along a gravel bed river
}

\author{
Lorenzo Picco, Alessia Tonon, Riccardo Rainato, Mario Aristide Lenzi \\ Department of Land, Environment, Agriculture and Forestry, University of Padova, Italy
}

\begin{abstract}
Riverine environments can be very dynamic and complex systems, particularly because of the interaction between active channel and riparian land during flood events of different magnitude. In recent years increasing attention has been paid to large wood (LW), focusing on its role and impact along riverine systems and fluvial landscapes. This research aims to analyze the characteristics of LW recruitment as a consequence of a flood event along a reach of a gravel-bed river. The study was conducted on a $3 \mathrm{~km}$-long reach located in the middle course of the Piave River (north-eastern Italian Alps). A 20 m-wide buffer zone was considered along the floodplains and islands. Every standing tree in this buffer with diameter $\geq 0.10 \mathrm{~m}$ was measured manually (diameter breast height; height), whereas shrubs were not considered. The most common species in the study area are: Populus sp., Salix sp., Alnus sp., Carpinus sp., Fraxinus sp., Pinus sylvestris and Robinia pseudoacacia. An over bankfull flood $\left(\mathrm{Q}=1329 \mathrm{~m}^{3} \mathrm{~s}^{-1}\right.$; recurrence interval $=6$ years) in November 2014 caused erosions along the
\end{abstract}

Correspondence: Lorenzo Picco, Department of Land, Environment, Agriculture and Forestry, University of Padova, via dell'Università 16, 35020 Legnaro (PD), Italy.

E-mail: lorenzo.picco@unipd.it

Key words: Bank erosion; distance traveled; flood; gravel-bed river; large wood recruitment; riparian trees.

Acknowledgements: the authors would like to thank Alison Garside for revising the English.

Funding: this research is funded within the UNIPD research Project CPDA149091- WoodAlp: linking large Wood and morphological dynamics of gravel bed rivers of Eastern Italian Alps- 2014-16, the Project SedAlp: sediment management in Alpine basins, integrating sediment continuum, risk mitigation and hydropower, 83-4-3-AT, in the framework of the ETC Program Alpine Space 2007-13, and the Italian Research Project of Relevant Interest PRIN2010-2011, prot. 20104ALME4; ITSE: National network for monitoring, modeling, and sustainable management of erosion processes in agricultural land and hilly-mountainous area.

Received for publication: 28 June 2015.

Accepted for publication: 14 February 2016.

CC Copyright L. Picco et al., 2016

Licensee PAGEPress, Italy

Journal of Agricultural Engineering 2016; XLVII:488

doi:10.4081/jae.2016.488

This article is distributed under the terms of the Creative Commons Attribution Noncommercial License (by-nc 4.0) which permits any noncommercial use, distribution, and reproduction in any medium, provided the original author(s) and source are credited. floodplain $\left(15,565.5 \mathrm{~m}^{2}\right)$, pioneer islands $\left(25.2 \mathrm{~m}^{2}\right)$ and building islands $\left(2085.6 \mathrm{~m}^{2}\right)$, recruiting 690 trees. Four of these trees were recruited from the pioneer islands $\left(0.16\right.$ tree $\left.\mathrm{m}^{-2}\right), 79$ from building islands $\left(0.04\right.$ tree $\left.\mathrm{m}^{-2}\right)$ and 607 from floodplains $\left(0.04\right.$ tree $\left.\mathrm{m}^{-2}\right)$. Accurate dendrometric measurements were used to define the input volume of $\mathrm{LW}$ from the floodplains $\left(86.25 \mathrm{~m}^{3}\right)$, pioneer islands $(0.14$ $\left.\mathrm{m}^{3}\right)$ and building islands $\left(6.62 \mathrm{~m}^{3}\right)$. The maximum distance traveled by LW recruited from the floodplain, pioneer and building islands was 8927,1021 and $3727 \mathrm{~m}$, respectively. Statistical analysis showed no significant relationship between the displacement and LW characteristics considered (diameter, length, volume, density). These results demonstrate that the recruitment and subsequent transport of LW is a complex mechanism that requires further study. To better characterize these mechanisms, it appears clear that it is important to consider not only the LW characteristics but also the connection between LW, morphological settings, and flood event characteristics.

\section{Introduction}

Riverine environments are dynamic and complex systems resulting from the interactions between water, sediment and vegetation. Given their position as ecotones between rivers and surrounding land (Naiman et al., 1998; National Research Council, 2002; Nilsson and Svedmark, 2002), riparian areas can feature a high level of biodiversity (Francis et al., 2008) and play an important role in enhancing biocomplexity within river corridors (Gurnell et al., 2005). They are closely linked with the active channel (identified as the area flooded during bankfull events) through the interaction between riparian vegetation and sediment fluxes, with the transfer of large wood (Lienkeamper and Swanson, 1987) that enters the channel and is deposited within the active area (Francis et al., 2008). Large wood (LW) is defined as a woody element, dead or alive, $>10 \mathrm{~cm}$ in diameter and/or $1 \mathrm{~m}$ in length (Marcus et al., 2002). It is a typical component of streams and rivers flowing through forested landscapes (Abbe and Montgomery, 2003), which plays an important function for geomorphological and ecological settings (Keller and Swanson, 1979; Bilby, 1981; Bisson et al., 1987). Large wood may also represent a risk for human structures, particularly during high magnitude flood events that can transport huge amounts of wood (Mazzorana et al., 2009).

In recent years, several researches have focused on LW (Lienkaemper and Swanson, 1987; Piégay and Gurnell, 1997; Gurnell and Petts, 2002; Piégay, 2003; Mao et al., 2008; Seo et al., 2010; Gurnell, 2013; Wohl, 2013; Tonon et al., 2014). More in detail, most studies have been focused on the characteristics and distribution of LW (Abbe and Montgomery, 1996; Piégay et al., 1999; Abbe and Montgomery, 2003; Hassan et al., 2005), its in-channel abundance (Bilby and Likens, 1980; Gregory et al., 1993; Iroumé et al., 2010; Ravazzolo et al., 2015a) and mobility (Braudrick et al., 1997; Bocchiola et al., 2002; Daniels, 2006; MacVicar and Piégay, 2012; Iroumé et al., 2015; Ravazzolo et al., $2015 \mathrm{~b})$. The recruitment of LW from riparian zones has been analyzed in fewer works because of the complex interaction between the active 
area and riparian vegetation (Downs and Simon, 2001). The recruitment of LW from riparian landforms and its dynamics varies (Golladay et al., 2007) according to the fluvial system characteristics. Along loworder mountain streams, the recruitment of LW is mainly connected to colluvial processes such as landslides and debris flows (Keller and Swanson, 1979), whereas bank erosion processes were identified as the main drivers of LW supply in wider rivers (Sedell and Froggatt, 1984; Gurnell et al., 2000; Downs and Simon, 2001; Moulin and Piégay, 2004; Lassettre et al., 2008; Ulloa et al., 2015). Lateral erosion may occur along both outer banks and island margins (Bertoldi et al., 2013). Moreover, LW can fall into the active channel after natural mortality processes that are related to riparian forest characteristics such as age, density, and health status. The LW input rates typically increase downstream (Hooke, 1980) and vary across river networks depending on erodibility of banks, flow energy, flood frequency and magnitude, and stand density (Benda and Sias, 2003). An understanding of the dynamics of LW recruitment is also important to better protect and enhance aquatic habitats (Van der Nat et al., 2003; Gurnell et al., 2005; Pollock and Beechie, 2014), as well as to forecast LW input during ordinary and extraordinary events (i.e., floods, landslides, windstorms). During the last two decades increasing attention has been paid to the mechanisms of LW recruitment (Palik et al., 1998; Benda et al., 2002, 2003), delivery rates of LW into rivers (Eaton et al., 2012) and fate of eroded trees
(Bertoldi et al., 2013). The assessment of LW recruitment is based on direct and indirect techniques. Field measurements have been applied to estimate the importance of different processes (i.e., mortality, bank erosion, landslides) on the LW recruitment rates (Benda et al., 2002 May and Gresswell, 2003), to compare recruitment rates from different riparian landforms and during different flood conditions (Palik et al., 1998; Golladay et al., 2007; Surian et al., 2015). The main advances achieved by indirect techniques regard the development of LW recruitment models that can estimate the input derived from hillslope instabilities (Rigon et al., 2012), predict LW input according to riparian characteristics, channel morphology and bank instability (Downs and Simon, 2001), and detect the LW supply during windthrow events (Bahuguna et al., 2010). Nonetheless, knowledge on LW recruitment needs to be broadened, especially in large rivers where extensive sections of floodplains may be eroded during flood events, delivering considerable volumes of LW into the active area (Piégay et al., 1999).

This study aims to increase the knowledge concerning LW recruitment rates in a reach of a piedmont gravel bed river, investigating the effects induced by a low frequency/high magnitude flood event. Field surveys were conducted before and after a flood event. Based on these surveys of standing riparian vegetation and banks retreat, this paper provides details on the rates of LW delivery by bank erosion from different morphological units (i.e., floodplains and fluvial islands). In addi-

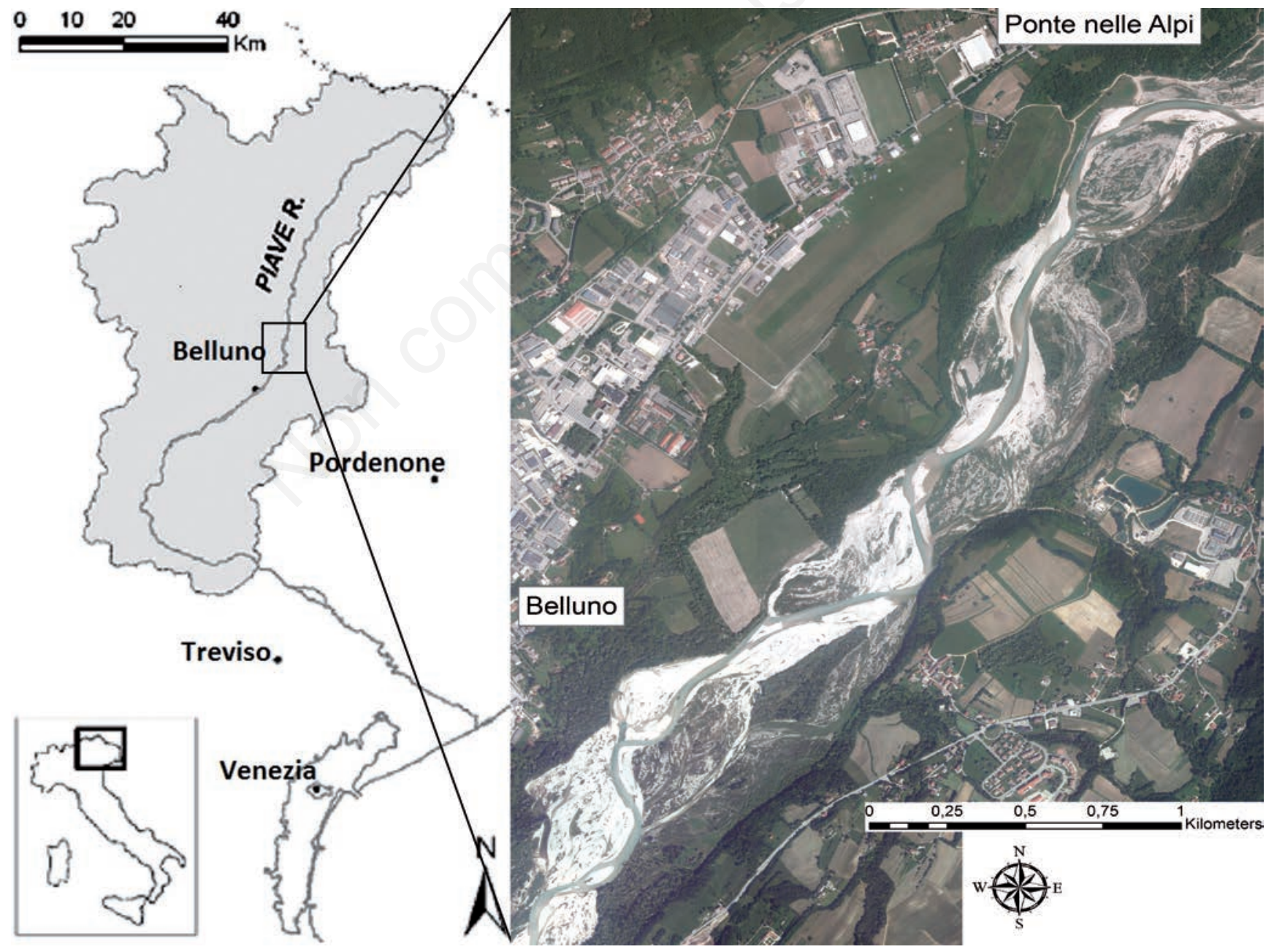

Figure 1. Piave River study reach and its location in the Veneto region (North-East Italy). 
tion, the dynamics of recruited trees was investigated in terms of distance traveled and downstream deposition sites, linking the behavior of eroded riparian vegetation to river morphology.

\section{Materials and methods}

\section{Study site and characteristics}

The Piave River basin is located in the North East of Italy and drains an area of $3899 \mathrm{~km}^{2}$, mainly composed of sedimentary rocks (i.e., limestone, dolomite) (Surian, 1996). In recent years many investigations have been conducted on the basin (Picco et al., 2012b; Delai et al., 2013; Rigon et al., 2013). The river flows for $222 \mathrm{~km}$ from its source in the Dolomites (2037 m a.s.l.) to its mouth on the Adriatic Sea coast. The climate of the whole basin is temperate-humid with mean annual precipitation of $1350 \mathrm{~mm}$. The most consistent floods typically happen in spring and autumn as a result of snowmelt and the rainiest period, respectively.

It is considered to be a highly disturbed river, as it has suffered multiple human impacts that altered the basin and river channel (Comiti et al., 2011). Most human activities have been carried out since the 1930 s when the flow was regulated by a series of dams built along the main channel and tributaries, intercepting more than $50 \%$ of sediment (Comiti et al., 2011). Between the 1960s and 1990s, intensive gravel mining induced important morphological channel responses such as narrowing and incision that generated a change from braided to wandering morphology (Comiti et al., 2011).

This study was conducted on a $3 \mathrm{~km}$-long reach (Figure 1) located near the village of Ponte nelle Alpi (Belluno Province). The study reach has maximum and mean width of about 435 and $267 \mathrm{~m}$, respectively, and an average slope of $0.0033 \mathrm{~m} \mathrm{~m}^{-1}$ (Picco et al., 2016). There are three bank protections along the right bank, whereas the left bank is confined by a floodplain and terraces. There are no tributaries within the study reach. The analyzed study site presents a complex pattern of vegetation (Picco et al., 2012a). The narrowing and incision phase during the $20^{\text {th }}$ century (Comiti et al., 2011) has allowed the colonization of large areas by riparian forests (Picco et al., 2012a). Furthermore, the widening tendency shown during the last 20 years has led to the creation of pioneer islands through LW recruitment from bank erosions (Picco et al., 2012a). In fact, the study reach contains several islands of different age and size, with a large complex established island in the middle part (Picco et al., 2014) that is gradually merging with the adjacent floodplain. More information on the vegetation characteristics, floodplain settings and island dimensions can be found in Picco et al. (2016) and Sitzia et al. (2015).

\section{Hydrological data}

The hydrological data used in the study were provided by a gauging station located $2 \mathrm{~km}$ downstream of the study reach. As already stated by Comiti et al. (2011), the bankfull discharge is equal to $700 \mathrm{~m}^{3} \mathrm{~s}^{-1}$. The last over bankfull flood [recurrence interval (RI) $=6$ years] occurred in November 2014, with a peak discharge recorded of $1329 \mathrm{~m}^{3}$ $\mathrm{s}^{-1}$ (Figure 2). During the flood the water discharge remained over the bankfull level for 1.58 days $(38 \mathrm{~h})$.

\section{Large wood recruitment data collection}

In order to better analyze LW recruitment, two data sources were used: field surveys of standing riparian vegetation and bank erosion measurements. A 20 m-wide buffer zone was considered along the floodplain and islands, defined on the basis of mean bank erosion width detected during the period 2006-2014 (unpublished data). In this buffer, every standing tree $(\mathrm{n}=3220)$ with diameter $\geq 0.10 \mathrm{~m}$ was measured manually (diameter breast height; height). In addition, the species and GPS position (average accuracy $\pm 0.40 \mathrm{~m}$ ) of each tree were recorded and a numbered tag was attached in order to simplify the post event recovery. After the first field campaign, the volume of each standing tree was calculated using the Algan-Monnin formula (Rondeux, 1993). A wood density value was assigned according to species.

The floodplain bank and island perimeters were surveyed before and after the November 2014 flood event. The islands were classified, according to Picco et al. (2014), as pioneer or building, while the stable type were not identified in the field. Thus pioneer islands (P), building islands (B) and floodplain (F) were considered. Bank erosion was evaluated using a DGPS device (average accuracy $\pm 0.025 \mathrm{~m}$ ). Eroded areas on the floodplain and islands were defined comparing the pre and post flood conditions using ArcGIS 10.1 (Environmental Systems Research Institute - Esri, Inc., Redlands, CA, USA). By means of the numbered tags, a recovery analysis was conducted walking downstream for $10 \mathrm{~km}$, checking every LW deposited in the active channel, on the banks and islands. The GPS position (average accuracy $\pm 0.025 \mathrm{~m}$ ) of each recovered tree was recorded. Given the absence of instantaneous measurements of the distance traveled this was defined as the trajectory

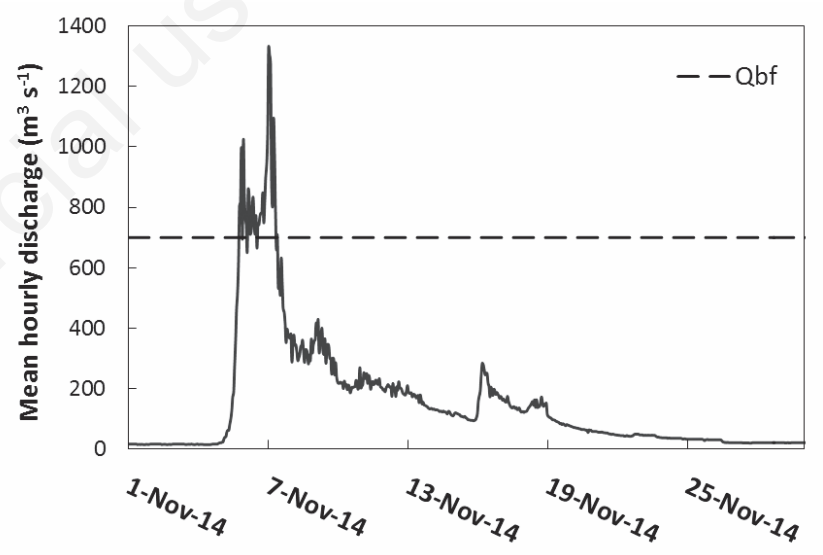

Figure 2. Mean hourly discharge on the Piave River as measured at Belluno gauging station during the over bankfull flood of November 2014. Dashed line indicates the bankfull discharge $\left(Q_{b f}=700 \mathrm{~m}^{3} \mathrm{~s}^{-1}\right.$, recurrence interval $=2$ years $)$.

Table 1. Wood density, based on Hellrigl (2006) (only recovered species are reported).

\begin{tabular}{lc} 
Species & Wood density $\left(\mathrm{g} \cdot \mathrm{cm}^{-3}\right)$ \\
Alnus sp. & 0.850 \\
Carpinus sp. & 1.000 \\
\hline Fagus sp. & 1.005 \\
Fraxinus sp. & 0.960 \\
\hline Picea abies & 0.860 \\
Pinus sylvestris & 0.880 \\
\hline Populus sp. & 0.840 \\
Robinia & 1.005 \\
\hline Salix sp. & 0.880 \\
\hline
\end{tabular}


between the starting standing point and the ending deposition point, following the middle line of the active channel.

\section{Statistical analysis}

Statistical analyses were performed using the STATISTICA (StatSoft, Inc., Tulsa, OK, USA) software. A linear regression was applied to test the relationships between erosion and recruitment rates, using the erosion surface as independent variable and the volume and number of recruited trees as dependent variables. An additional linear regression was implemented to examine possible relationships between some LW characteristics (diameter, length, volume, density) of recovered trees as independent variables and the traveled distance as dependent variable. Large Wood density was defined according to the species, and varied between 0.840 and $1.005 \mathrm{~g} \mathrm{~cm}^{-3}$ (Hellrigl, 2006) (Table 1). All regressions were considered statistically significant if $\mathrm{P} \leq 0.05$.

\section{Results}

\section{Riparian vegetation characteristics}

A total of 3220 riparian standing trees were surveyed within the 20 m-wide buffer zone along the floodplain and islands. Figure 3 gives the main dendrological characteristics of the trees recorded along each morphological unit. Looking at the diameters measured along the three morphological units (Figure 3A), pioneer islands are characterized by the lower median diameter $(0.11 \mathrm{~m})$, while building islands and floodplain area display the same median diameter of about $0.13 \mathrm{~m}$. Considering tree heights (Figure 3B), it is also clear that in this case pioneer islands feature the lower values (median of about $4 \mathrm{~m}$ ), whereas the median heights on building islands and floodplain reach 8 and 9 $\mathrm{m}$, respectively. Concerning the maximum values recorded, it is worth noting that the maximum diameter $(0.74 \mathrm{~m})$ and height $(28 \mathrm{~m})$ corresponds to trees belonging to Populus sp. located on the floodplain. The species composition of the three morphological units appears rather different (Table 2). According to what was already reported by Picco et al. (2016), the pioneer islands mainly have Salix sp. (94.40\%), and Populus sp. (1.40\%). The building islands are similar, with Salix sp. (76.40\%), Populus sp. (19.90\%), Alnus sp. (2.50\%), and Robinia pseudoacacia (1.20\%). The floodplain is characterized by a higher variability, containing also Carpinus sp. (7.60\%), Fraxinus sp. (14.80\%) and Pinus sylvestris (5.60\%).
A)

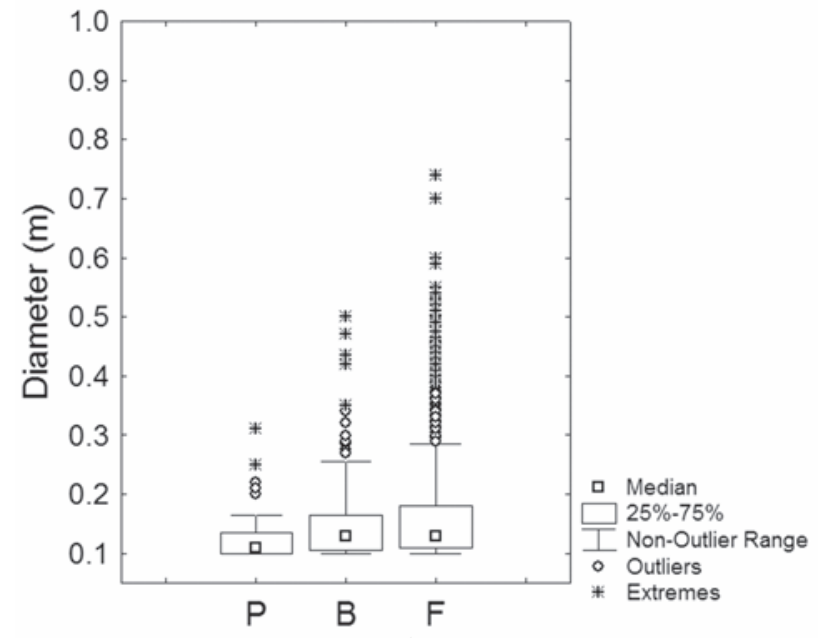

B)

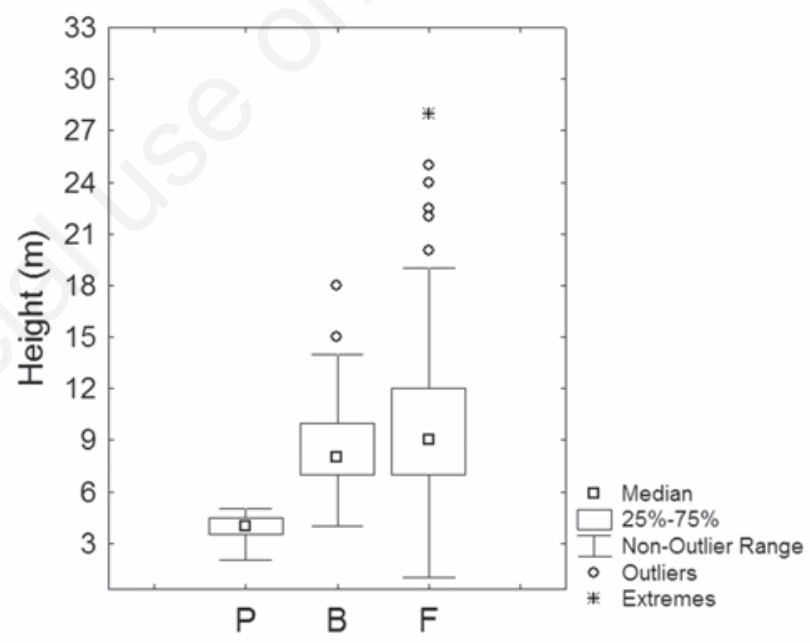

Figure 3. Diameter (A) and height (B) of tagged standing trees on the different morphological units ( $P$, pioneer islands; $B$, building islands; F, floodplain).

Table 2. Species composition differences on the morphological units. These data refer to the pre-flood condition.

\begin{tabular}{|c|c|c|c|c|c|c|}
\hline \multirow[t]{2}{*}{ Species } & \multicolumn{6}{|c|}{$\begin{array}{l}\text { Morphological unit } \\
\text { Building island }\end{array}$} \\
\hline & $\mathbf{N}$ & $\%$ & $\mathbf{N}$ & $\%$ & $\mathbf{N}$ & $\%$ \\
\hline Populus sp. & 1 & 1.4 & 32 & 19.9 & 160 & 5.4 \\
\hline Salix sp. & 68 & 94.4 & 123 & 76.4 & 842 & 28.2 \\
\hline Alnus sp. & - & - & 4 & 2.5 & 362 & 12.1 \\
\hline Robinia pseudoacacia & - & - & 2 & 1.2 & 446 & 14.9 \\
\hline Carpinus sp. & - & - & - & - & 226 & 7.6 \\
\hline Fraxinus sp. & - & - & - & - & 443 & 14.8 \\
\hline Pinus sylvestris & - & - & - & - & 166 & 5.6 \\
\hline Other species & - & - & - & - & 304 & 10.2 \\
\hline Unidentifiable & 3 & 4.2 & - & - & 36 & 1.2 \\
\hline
\end{tabular}




\section{Erosion and large wood recruitment rates}

During the over bankfull flood in November 2014, many vegetated patches were eroded. Figure 4 shows in detail eroded area, number of recruited trees, and volume of $\mathrm{LW}$ input for each area eroded area along the islands (Figure 4A) and floodplain (Figure 4B). Table 3 summarizes these values for different morphological units, considering also vegetation density of the eroded area and characteristics of recruited trees.

Three pioneer islands were eroded during the flood event with an eroded area that ranged from a minimum of about $3.16 \mathrm{~m}^{2}$ to a maximum of about $11.95 \mathrm{~m}^{2}$. A total of four trees were recruited, introducing $0.14 \mathrm{~m}^{3}$ of wood into the active channel. Ten building islands were eroded during the flood event, the eroded area ranged from $11.56 \mathrm{~m}^{2}$ to $953.00 \mathrm{~m}^{2}$, and there was a total input of about 79 trees corresponding to $6.62 \mathrm{~m}^{3}$. Six floodplain areas were also eroded (Figure 4B). Along two of these, erosions wider than $20 \mathrm{~m}$ were identified, with a maximum width of about $80 \mathrm{~m}$ along the left bank. In this study, the recruitment of LW was considered only for the data concerning the $20 \mathrm{~m}$-wide buffer along the $3 \mathrm{~km}$-long study reach. Looking at the six areas eroded along the floodplain, it is possible to see that each area contributes a different volume of LW. For example, two patches (F_1; F_3) of similar extension $\left(4922.99 \mathrm{~m}^{2}\right.$ and $\left.5128.71 \mathrm{~m}^{2}\right)$ were eroded along the left riverbank
(Figure 4B) but, because of the different tree densities ( 0.003 and $0.038 \mathrm{~N} \mathrm{~m}^{-2}$, respectively), they produced different $\mathrm{LW}$ input rates of about $0.84 \mathrm{~m}^{3}$ and $23.69 \mathrm{~m}^{3}$, respectively. Considering the overall values of the different morphological units (Table 3), the floodplain is the one most intensely eroded $\left(15,565.5 \mathrm{~m}^{2}\right)$, whereas pioneer and building islands have been less intensely eroded $\left(25.2 \mathrm{~m}^{2}\right.$ and $2085.6 \mathrm{~m}^{2}$, respectively). Pioneer islands are characterized by the highest density $(0.16$ tree $\left.\mathrm{m}^{-2}\right)$, but their erosion generated a very low input of $\mathrm{LW}\left(0.14 \mathrm{~m}^{3}\right)$, because of the small-eroded area $\left(25.2 \mathrm{~m}^{2}\right)$. The greatest erosions occurred along both building islands and floodplain, resulting in higher LW inputs of $6.62 \mathrm{~m}^{3}$ and $86.25 \mathrm{~m}^{3}$, respectively. These higher inputs are also due to the larger mean diameter and height with respect to the trees of pioneer islands. No direct correlations were found between the erosion surface and either the number of trees recruited $\left(R^{2}=0.052\right)$ or the input volume of $\mathrm{LW}\left(\mathrm{R}^{2}=0.037\right)$ (Figure 5).

\section{Large wood recovery and travel distance}

During the November flood, 690 trees were recruited, 228 (33.04\%) were recovered within the bankfull width along the $10 \mathrm{~km}$ stretch downstream from the upper eroded area. A wide range of variability in displacement distance was measured (Table 4). Three trees from pio-
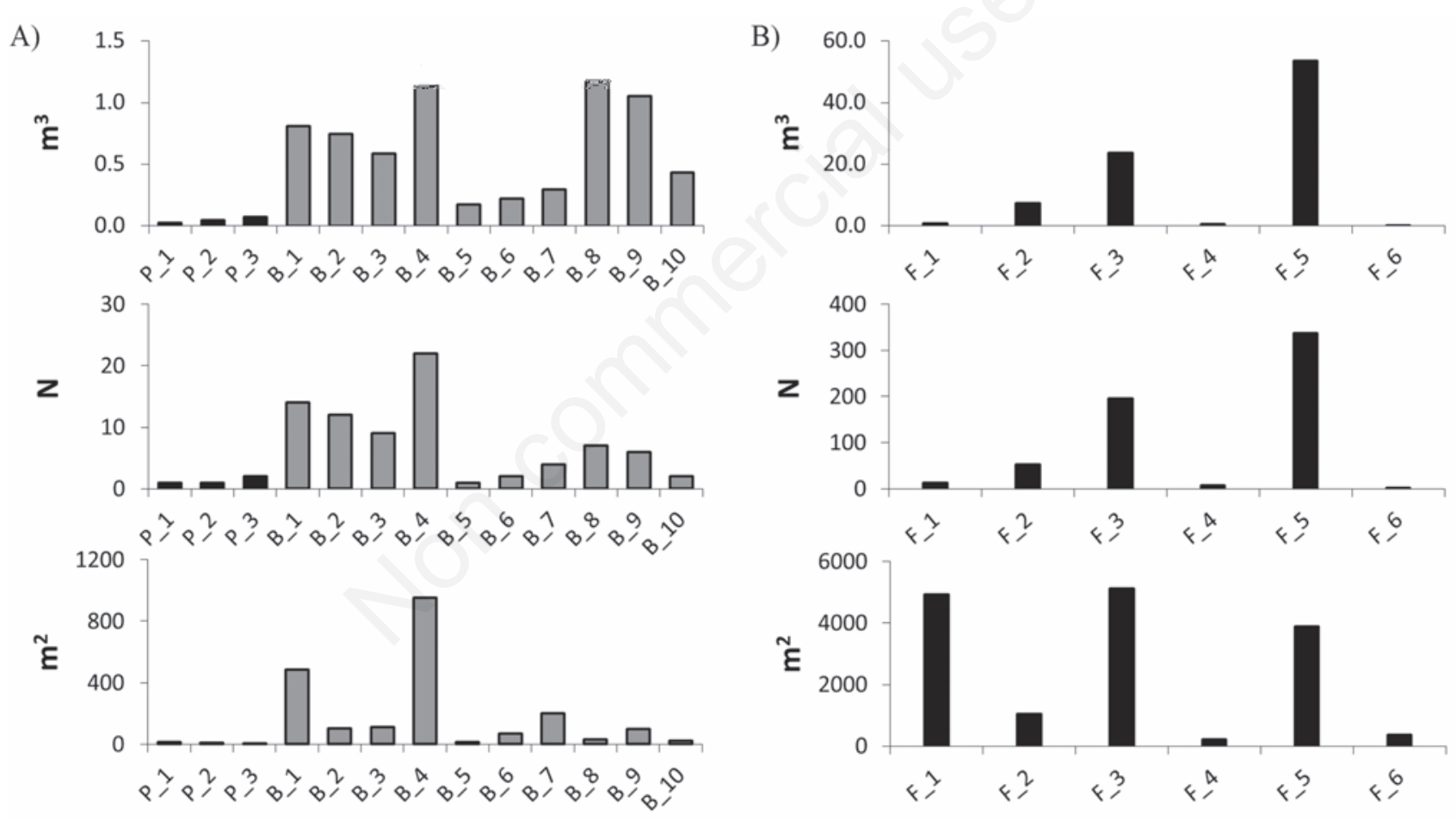

Figure 4. Bank erosion $\left(\mathrm{m}^{2}\right)$, number of recruited trees $(\mathrm{N})$ and large wood input $\left(\mathrm{m}^{3}\right)$ for each erosion source, islands (A) and floodplain (B). Letters on $x$-axis indicate the feature code of each area (P, pioneer islands; $B$, building islands; $F$, floodplain) in progressive order downstream.

Table 3. Erosion and recruitment rates for different morphological units.

\begin{tabular}{|c|c|c|c|c|c|c|c|}
\hline Morphological unit & $\begin{array}{c}\text { Area eroded } \\
\left(\mathrm{m}^{2}\right)\end{array}$ & $\begin{array}{l}\text { Tree recruited } \\
(\mathrm{N})\end{array}$ & $N \cdot m^{-2}$ & $\begin{array}{c}\text { Mean height } \\
\text { (m) }\end{array}$ & $\begin{array}{l}\text { Mean diameter } \\
\text { (m) }\end{array}$ & $\begin{array}{l}\text { Total volume } \\
(\mathrm{V})\left(\mathrm{m}^{3}\right)\end{array}$ & $\begin{array}{l}\text { Mean volume } \\
\left(\mathrm{V} \cdot \mathrm{N}^{-1}\right)\left(\mathrm{m}^{3}\right)\end{array}$ \\
\hline Pioneer island & 25.2 & 4 & 0.16 & 4.00 & 0.11 & 0.14 & 0.04 \\
\hline Building island & 2085.6 & 79 & 0.04 & 7.10 & 0.13 & 6.62 & 0.08 \\
\hline Floodplain & $15,565.5$ & 607 & 0.04 & 8.20 & 0.14 & 86.25 & 0.14 \\
\hline
\end{tabular}


neer islands were recovered within a range of $122 \mathrm{~m}$ to $1021 \mathrm{~m}$. Instead, only 27 trees from building islands were found within the surveyed area with minimum and maximum displacement distances of about 2 $\mathrm{m}$ and $3737 \mathrm{~m}$, respectively. The highest distance traveled (8927 m) was reached by a floodplain tree.

The LW recruited along the pioneer islands did not travel for more than 1-1.5 km, while the maximum distances were reached by trees recruited along the floodplain.

Figures 6 and 7 shows the relationship between the traveled distance and some dendrological and physical characteristics of the recovered LW: diameter, length, volume and density. No significant relationships $(\mathrm{P} \leq 0.05)$ were found between these features and the traveled distance (Table 5). Differently to what was expected, there are no clear relationships between the dendrological features and $\mathrm{LW}$ displacement. The stronger correlation $\left(\mathrm{R}^{2}=0.16\right)$, although not statistically significant $(\mathrm{P}=0.286)$, was found between wood density and mean traveled distance.

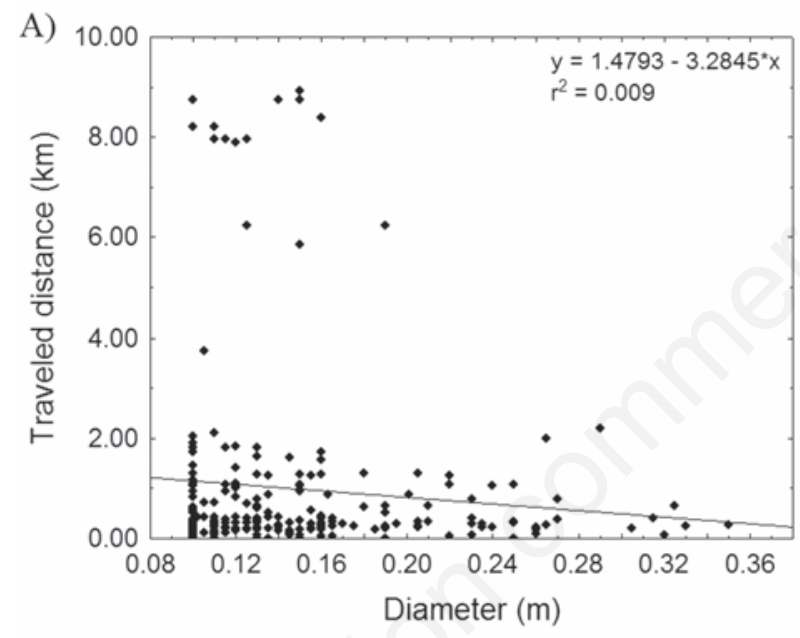

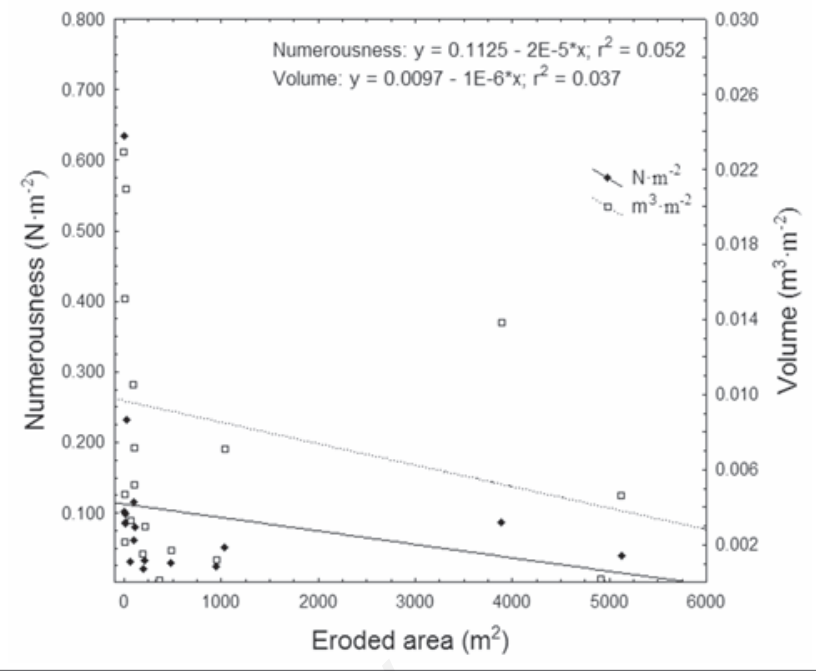

Figure 5. Relationship between eroded area and recruited large wood in terms of numerousness of trees and volume.

Figure 6. Relationship between traveled distance and large wood (LW) diameter (A), and LW length (B).

Table 4. Recovery rate and large wood traveled distance for different morphological units.

\begin{tabular}{lccccc} 
Morphological unit & $\begin{array}{c}\text { Tree recovered } \\
(\mathrm{N})\end{array}$ & $\begin{array}{c}\text { Recovery rate } \\
(\%)\end{array}$ & $\begin{array}{c}\text { Minimum traveled } \\
\text { distance }(\mathrm{m})\end{array}$ & $\begin{array}{c}\text { Maximum traveled } \\
\text { distance }(\mathrm{m})\end{array}$ & $\begin{array}{c}\text { Mean traveled } \\
\text { distance }(\mathrm{m})\end{array}$ \\
Pioneer island & 3 & 75.0 & 122 & 1021 & 422 \\
Building island & 27 & 34.0 & 2 & 3737 & 623 \\
\hline Floodplain & 128 & 32.6 & 1 & 8927 & 1052 \\
\hline
\end{tabular}

Table 5. Summary of the regression analysis between mean traveled distance and dendrological characteristics of recovered large wood.

\begin{tabular}{lcccc} 
Dependent variable $(\mathrm{km})$ & Independent variable & Equation & $\mathrm{R}^{2}$ & Statistical significance \\
Traveled distance & $\mathrm{D}_{\mathrm{LW}}(\mathrm{m})$ & $\mathrm{y}=1.4793-3.2845^{*} \mathrm{x}$ & 0.009 & Not significant $(0.154)$ \\
Traveled distance & $\mathrm{L}_{\mathrm{LW}}(\mathrm{m})$ & $\mathrm{y}=1.6496-0.0762^{*} \mathrm{x}$ & 0.014 & Not significant $(0.071)$ \\
\hline Traveled distance & $\mathrm{V}_{\mathrm{LW}}\left(\mathrm{m}^{3}\right)$ & $\mathrm{y}=1.2024-1.4792^{*} \mathrm{x}$ & 0.014 & Not significant $(0.069)$ \\
Mean traveled distance & $\rho_{\mathrm{LW}}\left(\mathrm{g} \mathrm{cm}^{-3}\right)$ & $\mathrm{y}=3.162-2.540 * \mathrm{x}$ & 0.160 & Not significant $(0.286)$ \\
\hline
\end{tabular}




\section{Discussion}

The results highlighted that the over bankfull flood of November 2014 caused different erosions along the three morphological units considered: floodplain, pioneer islands and building islands (Picco et al., 2014). These morphological units are characterized by different vegetation density that influenced the number and volume of recruited trees. The differences are directly connected to their morphological development that permitted the generation and stabilization of different vegetated communities (Sitzia et al., 2015; Picco et al., 2016). Pioneer islands present the highest tree density $\left(0.16 \mathrm{~N} \mathrm{~m}^{-2}\right)$, and should be the morphological unit that provides the highest recruitment of trees but, since the erosion is the lowest $\left(25 \mathrm{~m}^{2}\right)$, the effective recruitment of $\mathrm{LW}$ is quite negligible $\left(0.14 \mathrm{~m}^{3}\right)$. In contrast, the floodplain and building islands generated a higher input of LW into the channel thanks to the greater erosion verified along their edges. The most important of these is the floodplain, which contributed $92.73 \%$ of the total LW volume. Similar results were observed by Piégay et al. (1999) along a wandering French river (Drôme River), with an input of LW from the floodplains of about $82 \%$ and $62 \%$ in two different periods. Contrary to what has been reported by many authors (Bertoldi et al., 2009; Comiti et al., 2011; Mikus et al., 2013; Moretto et al., 2014), during the not extraordinary November 2014 flood, a considerable volume of $\mathrm{LW}$ was recruited from the short study reach considered here. This is in agreement with a recent publication in which the authors found that riparian vegetation can also be considerably eroded during low magnitude floods (RI $\leq 2-3$ years) (Surian et al., 2015).

During the post flood field survey, $33.04 \%$ of recruited trees were recovered. This value is similar to the results presented by Schenk $e t$ al. (2014) along the Roanoke River. They reported a recovery rate lower than 40\% using RFID tags. Ravazzolo et al. (2015b), again using RFID tags, had a recovery rate from $42 \%$ to $43 \%$ along the Tagliamento River. Despite the attachment of simple metallic tags, our recovery rate is higher than those presented by MacVicar et al. (2009). They used RFID to monitor LW displacement along the Ain River, obtaining recovery rates from $13 \%$ to $27 \%$. Therefore, despite the limitations of the type of metallic tags, the recovery rate obtained is comparable, or even better, than the proportion of tagged logs recovered using radio markers. This is probably because radio markers can be affected by prolonged permanence in humid conditions that can compromise their functioning.

The LW displacement distances recorded during the November 2014 flood allow us to better understand some recruitment mechanisms, or at least give us more information for a better analysis of these phenomena. In fact, the longer travel distance recorded for trees recruited from the floodplain suggests that the floodplain was probably eroded during the initial increasing phase. Contrary to what had been expected, the fluvial islands (both pioneer and building) were probably better able to resist the flood, maintaining their position in the active channel. This can be justified by the presence of wood jams upstream of the islands that protect them from the erosional forces of the flood. Moreover, the vegetation of these islands (Table 2) is characterized by high flexibility, particularly due to young ages. This can greatly increase the ability to survive floods. The shorter displacement of trees recovered along islands also suggests that they were recruited during the long receding phase of the flood.

These assumptions on bank erosion and LW recruitment dynamics confirm those of Bertoldi et al. (2013), who used field measurements, ground-based images and a LiDAR survey to quantify the input of LW through bank erosion along the Tagliamento River.

Post event field analysis allowed us to obtain information on the most suitable deposition area. In agreement with Mao et al. (2012) and Ravazzolo et al. (2015b), we found that about $96.90 \%$ of recruited LW was deposited along gravel bars, while just a couple of trees (1.31\%) were deposited upstream of building islands. This confirms that fluvial islands can interact with LW, promoting island development (Gurnell et al., 2005). Moreover, it can be observed that LW was also deposited on the riverbanks (1.31\%), implying further considerations for budget computation (Keller and Swanson, 1979; Benda and Sias, 2003).

It is also interesting that a large amount of LW eroded from the F_5 area was deposited nearby after a very short displacement. Around $30 \%$ of the total LW recruited upstream was deposited in this area, and $80 \%$ of the LW recruited from F_5 was immediately deposited on this gravel bar, forming wood jams. These results are similar to the observations of Bertoldi et al. (2013) on the braided Tagliamento River, where up to $40 \%$ of recruited trees were deposited on the nearest downstream bar.
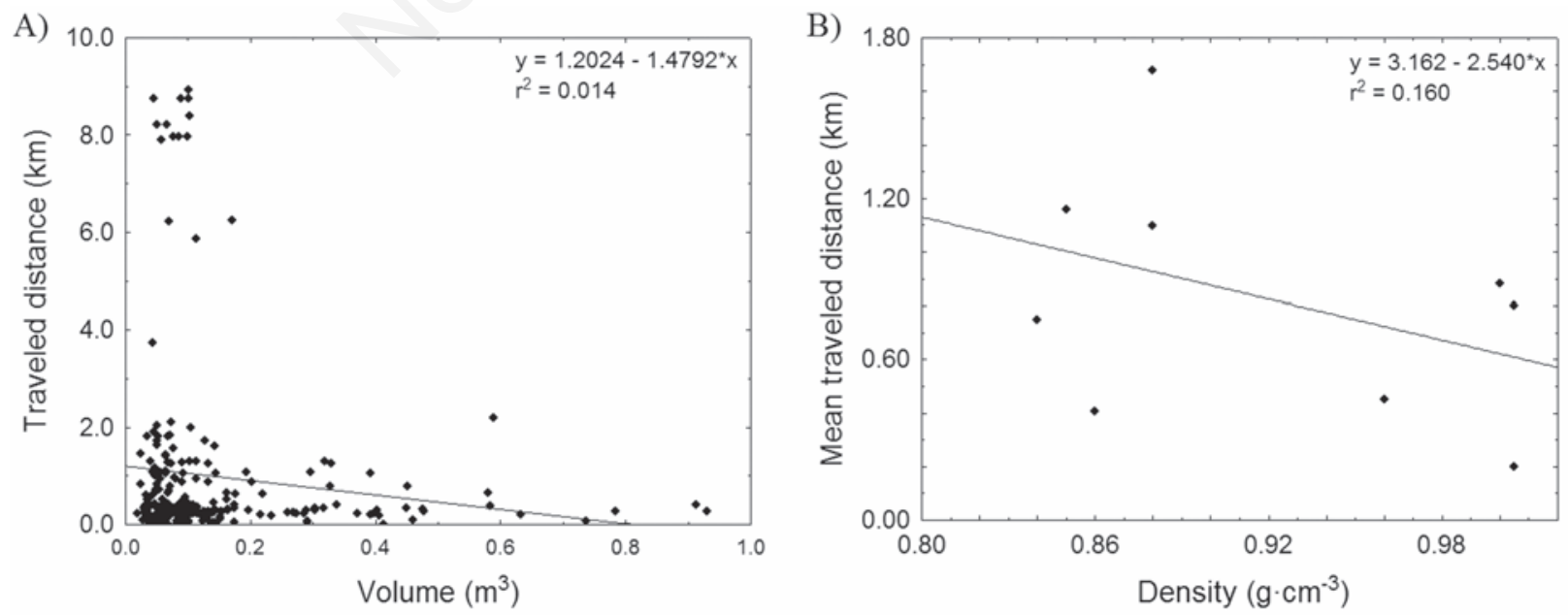

Figure 7. Relationship between traveled distance and large wood (LW) volume (A), and LW density (B). 
This deposition process can be related to the behavior of both LW and sediment transport. In fact, as reported by Pyrce and Ashmore (2003), sediments delivered into channels during bank erosion processes are deposited on a nearby bar. This typically happens on the first bar immediately downstream of the eroded area, enhancing the development of suitable features (i.e., high bars) for the deposition of LW. However, the type of LW transport can have affected its displacement and deposition. In this sense, considering the ratio between the volume of LW recruited (Qlog) and the water discharge (Qw) (Braudrick et al., 1997), it is possible that the displacement occurred in a congested regime of transport in which the LW elements moved together and were unable to move independently of each other. A high degree of interaction among logs usually results in short transport distances and deposition in wood jams (Braudrick et al., 1997).

The statistical analysis related to the LW transport did not identify clear relationships between the traveled distance and main LW characteristics, highlighting that the mobility of LW is probably also governed by other factors or by their combination. This is also confirmed by other analyses conducted in this study. In fact, contrary to what was reported by Welber et al. (2013) and Ruiz-Villanueva et al. (2015), in this case there are no significant correlations between LW displacement and its diameter. Instead, the lack of statistical significance in the relationship between traveled distance and LW length agrees with Ruiz-Villanueva et al. (2015). In this case, the authors found that in wide multi-thread reaches the importance of $\mathrm{LW}$ length is not so evident as in the singlethread channel cases. Contrary to what was expected and reported by Ruiz-Villanueva et al. (2015), the relationship between traveled distance and wood density was also not statistically significant and the traveled distance does not seem to be influenced by wood density, demonstrating once again the complexity of the analyzed process. The recruitment of standing trees from the banks and their subsequent transport downstream is a highly complex process because it is not possible to consider independent factors and characteristics, but there is a need to analyze their combination.

\section{Conclusions}

Not extraordinary floods can affect vegetated patches contributing to the input of LW into channels. These flood events can interact differently with morphological units characterized by differences in vegetation cover and morphological settings. In riverine systems like the Piave River, it is possible to observe huge bank erosion processes along both floodplain and building islands. These morphological units have mature vegetation cover that produces the input of big trees into the channels. The subsequent downstream transport of LW appears to be a very complex process. The results presented here demonstrate that there are complex and not clear relationships between the controlling factors typically taken into account when LW recruitment and its transport are considered separately. The evidence that LW transport happens in congested conditions is a further demonstration of the great complexity of these processes. In fact, the contemporary delivery of a huge amount of trees into channels can dramatically increase the intricacy of LW transport dynamics, due to the interaction and contact of canopy, roots and eroded sediment. It appears clear that there is a need to increase the analysis of these processes, considering also other aspects and settings. Further analyses will be performed in order to better understand the dynamics of recruitment and transport of LW in large rivers, taking into account other vegetation characteristics (i.e., canopy dimension, roots size), morphological features (i.e., geometric characteristics, presence of knick points), and hydrological characteristics (i.e., water stage).

\section{References}

Abbe T.B., Montgomery D.R. 1996. Large woody debris jams, channel hydraulics and habitat formation in large rivers. Reg. Rivers Res. Manage. 12:201-21.

Abbe T.B., Montgomery D.R. 2003. Patterns and processes of wood debris accumulation in the Queets river basin, Washington. Geomorphology 51:81-107.

Bahuguna D., Mitchell S.J., Miquelajauregui Y. 2010. Windthrow and recruitment of large woody debris in riparian stands. Forest Ecol. Manage. 259: 2048-55.

Benda L.E., Bigelow P., Worsley T.M. 2002. Recruitment of wood to streams in old-growth and second-growth redwood forests, northern California, USA. Can. J. Forest Res. 32:1460-77.

Benda L.E., Sias J.C. 2003. A quantitative framework for evaluating the mass balance of in-stream organic debris. Forest Ecol. Manage. 172:1-16.

Benda L., Miller D., Sias J., Martin D., Bilby R., Veldhuisen C., Dunne T. 2003. Wood recruitment processes and wood budgeting. American Fisheries Society Symposium: 49-74.

Bertoldi W., Gurnell A.M., Surian N., Tockner K., Zanoni L., Ziliani L., Zolezzi G. 2009. Understanding reference processes: linkages between river flows, sediment dynamics and vegetated landforms along the Tagliamento River, Italy. River Res. Appl. 25:501-16.

Bertoldi W., Gurnell A.M., Welber M. 2013. Wood recruitment and retention: the fate of eroded trees on a braided river explored using a combination of field and remotely-sensed data sources. Geomorphology 180:146-55.

Bilby R.E., Likens G.E., 1980. Importance of organic debris dams in the structure and function of stream ecosystems. Ecology 61:1107-13.

Bilby R.E. 1981. Role of organic debris dams in regulating the export of dissolved and particulate matter from a watershed. Ecology 62:1234-43.

Bisson P.A., Bilby R.E., Bryant M.D. 1987. Large woody debris in forested streams in the Pacific Northwest: past, present, and future. In: E.0. Salo, T.W. Cundy (Eds.), Streamside management: forestry and fishery interactions, vol. 57. Univ. of Washington, Institute of Forest Resources Contribution, Washington, DC, USA, pp. 143-190.

Bocchiola D., Catalano F., Menduni G., Passoni G. 2002. An analyticalnumerical approach to the hydraulics of floating debris in river channels. J. Hydrol. 269:65-78.

Braudrick C.A., Grant G.E., Ishikawa Y., Ikeda H. 1997. Dynamics of wood transport in streams: a flume experiment. Earth Surf. Process. Landforms 22:669-83.

Comiti F., Da Canal M., Surian N., Mao L., Picco L., Lenzi M.A. 2011. Channel adjustments and vegetation cover dynamics in a large gravel bed river over the last 200 years. Geomorphology 125:147-59.

Daniels M. 2006. Distribution and dynamics of large woody debris and organic matter in a low-energy meandering stream. Geomorphology 77:286-98.

Delai F., Moretto J., Mao L., Picco L., Lenzi M.A. 2013. Evaluation of short-term geomorphic changes in differently impacted gravel-bed rivers using improved dems of difference. J. Agric. Engine. XLIV(s2):122-7.

Downs P.W., Simon A. 2001. Fluvial geomorphological analysis of the recruitment of large woody debris in the Yalobusha River network, Central Mississippi, USA. Geomorphology 37:65-91.

Eaton B.C., Hassan M.A., Davidson S.L. 2012. Modeling wood dynamics, jam formation, and sediment storage in a gravel-bed stream. J. Geophys. Res. 117:F00A05.

Francis R.A., Tibaldeschi P., McDougall L. 2008. Fluvially-deposited large wood and riparian plant diversity. Wetlands Ecol. Manage. 
16:371-82.

Golladay S.W., Battle J.M., Palik B.J. 2007. Large wood debris recruitment on differing riparian landforms along a Gulf Coastal Plain (USA) stream: a comparison of large floods and average flows. River Res. Appl. 23:391-405.

Gregory K.J., Davis R.J., Tooth S. 1993. Spatial distribution of coarse woody debris dams in the Lymington Basin, Hampshire, UK. Geomorphology 6:207-24.

Gurnell A.M., 2013. Wood in fluvial systems. In: J. Shroder, E. Wohl (Eds.), Treatise on Geomorphology 9. Academic Press, San Diego, CA, USA, 9:163-88.

Gurnell A.M., Petts G.E., 2002. Island-dominated landscapes of large floodplain rivers, a European perspective. Freshwater Biol. 47: 581-600.

Gurnell A.M., Petts G.E., Hannah D.M., Smith B.P., Edwards P.J., Kollmann J., Ward J.V., Tockner K. 2000. Wood storage within the active zone of a large European gravel-bed river. Geomorphology 34:55-72.

Gurnell A., Tockner K., Edwards P., Petts G. 2005. Effects of deposited wood on biocomplexity of river corridors. Front. Ecol.Environ. 3:377-82.

Hassan M.A., Hogan D.L., Bird S.A., May C.L., Gomi T., Campbell D. 2005. Spatial and temporal dynamics of wood in headwater streams of the Pacific northwest. J. Am. Water Resour. Assoc. 41:899-919.

Hellrigl B. 2006. Elementi di xiloenergetica: definizioni, formule, tabelle. (Elements of wood energy). Associazione Italiana Energie Agroforestali (AIEL), Legnaro (PD), Italy.

Hooke J. 1980. Magnitude and distribution of rates of river bank erosion. Earth Surf. Process. 5:143-57.

Iroumé A., Andreoli A., Comiti F., Ulloa H., Huber A. 2010. Large wood abundance, distribution and mobilization in a third order Coastal mountain range river system, southern Chile. Forest Ecol. Manage. 260:480-90.

Iroumé A., Mao L., Andreoli A., Ulloa H., Ardiles M. P. 2015. Large wood mobility processes in low-order Chilean river channels. Geomorphology 228:681-93.

Keller E.A., Swanson F.J. 1979. Effects of large organic material on channel form and fluvial processes. Earth Surf. Process. 4:361-80.

Lassettre N.S., Piégay H., Dufour S., Rollet A.J. 2008. Decadal changes in distribution and frequency of wood in a free meandering river, the Ain River, France. Earth Surf. Process. Landforms 33:1098-12.

Lienkaemper G.W., Swanson F.J. 1987. Dynamics of large woody debris in streams in old-growth Douglas-fir forests. Can. J. Forest Res. 17:150-6.

MacVicar B.J., Piégay H., Henderson A., Comiti F., Oberlin C., Pecorari E. 2009. Quantifying the temporal dynamics of wood in large river: field trials of wood surveying, dating, tracking, and monitoring techniques. Earth Surf. Process. Landforms 34:2031-46.

MacVicar B., Piégay H. 2012. Implementation and validation of video monitoring for wood budgeting in a wandering piedmont river, the Ain River (France). Earth Surf. Process. Landforms 37:1272-89.

Mao L., Comiti F., Andreoli A., Picco L., Lenzi M.A., Urciuolo A., Iturraspe R., Iroumé A. 2008. Role and management of in-channel wood in relation to floods events in Southern Andes basins. WIT Trans. Engine. Sci. 60:207-16.

Mao L., Ravazzolo D., Picco L., Rigon E., Lenzi M.A. 2012. Types and volumes of in-channel wood in three Italian gravel-bed rivers suffering from different degrees of human disturbances. Proc. First International Conference on Integrative Sciences and Sustainable Development of Rivers, 26-28 June 2012, Lyon, France.

Marcus W.A., Marston R.A., Colvard Jr C.R., Gray R.D. 2002. Mapping the spatial and temporal distributions of woody debris in streams of the Greater Yellowstone Ecosystem, USA. Geomorphology 44:323-35.
May C.L., Gresswell R.E. 2003. Large wood recruitment and redistribution in headwater streams in the southern Oregon Coast Range, U.S.A. Can. Forest Res. 33:1352-62.

Mazzorana B., Zischg A., Largiader A., Hubl J. 2009. Hazard index maps for woody material recruitment and transport in alpine catchments. Nat. Hazards Earth Syst. Sci. 9:197-209.

Miku P., Wyzga B., Kaczka R.J., Walusiak E., Zawiejska J. 2013. Islands in a European mountain river: linkages with large wood deposition, flood flows and plant diversity. Geomorphology 202:115-27.

Moretto J., Rigon E., Mao L., Picco L., Delai F., Lenzi M.A., 2014. Channel adjustments and island dynamics in the Brenta River (Italy) over the last 30 years. River Res. Appl. 30:719-32.

Moulin B., Piégay H. 2004. Characteristics and temporal variability of large woody debris trapped in a reservoir on the River Rhone (Rhone): implications for river basin management. River Res. Appl. 20:79-97.

Naiman R.J., Fetherston K.L., McKay S., Chen J. 1998. Riparian forests. In: R.J. Naiman, R.E. Bilby (Eds.), River ecology and management: lessons from the Pacific coastal ecoregion. Springer-Verlag, New York, NY, USA, pp. 289-323.

National Research Council. 2002. Riparian areas: functions and strategies for management. National Academy Press, Washington, DC, USA.

Nilsson C., Svedmark M. 2002. Basic principles and ecological consequences of changing water regimes: riparian plant communities. Environ. Manage. 30:468-80.

Palik B., Golladay S.W., Goebel P.C., Taylor B.W. 1998. Geomorphic variation in riparian tree mortality and stream coarse woody debris recruitment from record flooding in a coastal plain stream. Ecoscience 5:551-60.

Picco L., Mao L., Rigon E., Moretto J., Ravazzolo D., Delai F., Lenzi M. A. 2012a. Riparian forest structure, vegetation cover and flood events in the Piave River. WIT Trans. Engine. Sci. 73:137-47.

Picco L., Mao L., Rigon E., Moretto J., Ravazzolo D., Delai F., Lenzi M.A. 2012b. An update of the sediment fluxes investigation in the Rio Cordon (Italy) after 25 years of monitoring. J. Agric. Engine. XLIII:108-13.

Picco L., Rainato R., Mao L., Delai F., Tonon A., Ravazzolo D., Lenzi M.A. 2013. Characterization of fluvial islands along three different gravelbed rivers of North-Eastern Italy. J. Agric. Engine. XLIV(s2):117-21.

Picco L., Mao L., Rainato R., Lenzi M.A. 2014. Medium term fluvial island evolution in a disturbed gravel bed river (Piave River, Northeastern Italian Alps). Geograf. Ann. Ser. A Phys. Geogr. 96:83-97.

Picco L., Sitzia T., Mao L., Comiti F., Lenzi M.A., 2016. Linking riparian woody communities and fluviomorphological characteristics in a regulated gravel-bed river (Piave river, Northern Italy). Ecohydrology 9:101-12.

Piégay H., Gurnell A.M. 1997. Large woody debris and river geomorphological pattern: examples from SE France and S. England. Geomorphology 19:99-116.

Piégay H., Thevenet A., Citterio A. 1999. Input, storage and distribution of large woody debris along a mountain river continuum, the Drôme River, France. Catena 35:19-39.

Piegay H. 2003. Dynamics of wood in large rivers. American Fisheries Society Symposium, 109-133.

Pollock M.M., Beechie T.J. 2014. Does riparian forest restoration thinning enhance biodiversity? The ecological importance of large wood. J. Am. Water Resour. Assoc. 50:543-59.

Pyrce R.S., Ashmore P.E. 2003. Particle path length distributions in meandering gravel-bed streams. Results from physical models. Earth Surf. Process. Landforms 28:951-66.

Ravazzolo D., Mao L., Picco L., Sitzia T., Lenzi M.A. 2015a. Geomorphic effects of wood quantity and characteristics in three Italian gravel- 
bed rivers. Geomorphology 246:79-89.

Ravazzolo D., Mao L., Picco L., Lenzi M.A. 2015b. Tracking log displacement during floods in the Tagliamento River using RFID and GPS tracker devices. Geomorphology 228:226-33.

Rigon E., Comiti F., Lenzi M.A. 2012. Large wood storage in streams of the Eastern Italian Alps and the relevance of hillslope processes. Water Resour. Res. 48:W01518.

Rigon E., Moretto J., Delai F., Picco L., Ravazzolo D., Rainato R., Lenzi M.A. 2013. Application of the new Morphological Quality Index in the Cordevole river (BL, Italy). J. Agric. Engine. XLIV(s2):48-53.

Rondeux J. 1993. La mesure des arbres et des peuplements forestiers. Les Presses Agronomiques de Gembloux, Gembloux, Belgium.

Ruiz-Villanueva V., Wy ga B., Zawiejska J., Hajdukiewicz M., Stoffel M. 2015. Factors controlling large-wood transport in a mountain river. Geomorphology [In press].

Schenk E.R., Moulin B., Hupp C.R., Richter J.M. 2014. Large-wood budget and transport dynamics on a large river using radio telemetry. Earth Surf. Process. Landforms 39:487-98.

Sedell J.R., Froggatt J.L. 1984. Importance of streamside forests to large rivers: the isolation of the Willamette River, Oregon, USA, from its floodplain by snagging and streamside forest removal. Int. Verein. Theor. Angew. Limnol. Verhand. 22:1828-34.

Seo J.I., Nakamura F., Chun K.W. 2010. Dynamics of large wood at the watershed scale: a perspective on current research limits and future directions. Landscape Ecol. Engine. 6:271-87.
Sitzia T., Picco L., Ravazzolo D., Comiti F., Mao L., Lenzi M.A., 2015. Relationships between woody vegetation and geomorphological patterns in three gravel-bed rivers with different intensities of anthropogenic disturbance. Adv. Water Resour. [In press].

Surian N. 1996. The terraces of Piave River in the Vallone Bellunese (Eastern Alps, Italy). Geograf. Fisica Dinam. Quatern. 19:119-27.

Surian N., Barban M., Ziliani L., Monegato G., Bertoldi W., Comiti F. 2015. Vegetation turnover in a braided river: frequency and effectiveness of floods of different magnitude. Earth Surf. Process. Landforms 40:542-58.

Tonon A., Picco L., Ravazzolo D., Lenzi M.A. 2014. Using a terrestrial laser scanner to detect wood characteristics in gravel-bed rivers. J. Agric. Engine. XLV:161-7.

Ulloa H., Iroumé A., Picco L., Korup 0., Lenzi M.A., Mao L., Ravazzolo D., 2015. Massive biomass flushing despite modest channel response in the Rayas River following the 2008 eruption of Chaitén volcano, Chile. Geomorphology 250:397-406.

Van der Nat D., Tockner K., Edwards P.J., Ward J.V. 2003. Large wood dynamics of complex Alpine river floodplains. J. North Am. Benthol. Soc. 22:35-50.

Welber M., Bertoldi W., Tubino M. 2013. Wood dispersal in braided streams: results from physical modeling. Water Resour. Res. 49:7388-400.

Wohl E. 2013. Floodplains and wood. Earth Sci. Rev. 123:194-212. 